\title{
Film o sprawie Dreyfusa
}

\author{
A Film about Dreyfus Affair
}

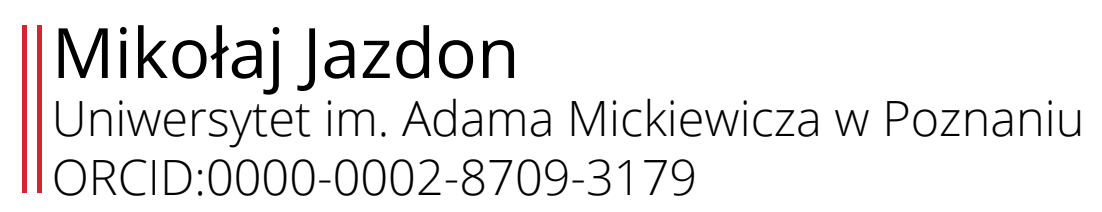

\begin{abstract}
The author analyzes Roman Polański's J'accuse (2019), a film about the Dreyfus affair, carefully examining selected movie scenes and sequences, showing how the director presents and exposes the topic of anti-Semitism, its roots in the military elite and part of the French society at the end of the 19th century. The case of the false accusation and conviction of an innocent officer of Jewish origin was shown in the film as a ominous foreshadowing of the coming century marked by the hecatomb of the Holocaust and earlier by the slaughter of millions of human lives on the fronts of The Great War. Polański's film alludes to both of these historical events. In the article, the author indicates references to other films in Polański's movie, not only those dealing with the Dreyfus affair and the famous article by Emil Zola, entitled J'accuse.
\end{abstract}

Key words: anti-Semitism, film history, film analysis, Holocaust, Roman Polański, Dreyfus affair, mise-en-scene

Streszczenie: Autor analizuje w swym artykule film Romana Polańskiego Oficer i szpieg, film o sprawie Dreyfusa, przyglądając się uważnie wybranym scenom i sekwencjom, pokazując, w jaki sposób reżyser przedstawia i eksponuje temat antysemityzmu, jego zakorzenienie w elitach wojskowych i części społeczeństwa Francji końca XIX wieku. Sprawa fałszywego oskarżenia i skazania niewinnego oficera żydowskiego pochodzenia została pokazana w filmie jako złowróżbna zapowiedź nadchodzącego stulecia naznaczonego hekatombą Holokaustu, a wcześniej rzezią milionów ludzkich istnień na frontach I wojny światowej. W filmie Polańskiego pojawiają się aluzje do obu tych wydarzeń z historii. Autor wskazuje w artykule na obecne w dziele Polańskiego odniesienia do innych dzieł filmowych, nie tylko tych podejmujących temat sprawy Dreyfusa i słynnego artykułu Emila Zoli J'accuse

Słowa kluczowe: antysemityzm, historia kina, analiza filmu, Holokaust, Roman Polański, sprawa Dreyfusa, scena filmowa, sekwencja filmowa, inscenizacja

W filmie Romana Polańskiego J'accuse (2019) dwa fragmenty przykuwają uwagę i w szczególny sposób zapadają w pamięć, oba reprezentują odmienny sposób opowiadania, mają inną siłę wyrazu i przemawiają 
na różny sposób. Otwierająca film scena ${ }^{1}$ publicznej degradacji kapitana Dreyfusa przed otaczającymi plac oddziałami ma charakter dokumentalnej rekonstrukcji, jest rodzajem rozłożonej na ujęcia analizy historycznego zdarzenia. Umieszczona blisko półtorej godziny później sekwencja² ${ }^{2}$ ilustrująca konsekwencje opublikowania przez Emila Zolę listu otwartego do prezydenta republiki, zgodnie z zastosowanym w niej rodzajem montażu, prezentuje efektowną syntezę zjawisk politycznych i społecznych wywołanych nowym wybuchem afery. W pierwszej scenie filmu w centrum uwagi pozostaje Alfred Dreyfus, człowiek w niezwykle dramatycznych okolicznościach swego życia, w sekwencji „efektu Zoli” Dreyfus-człowiek jest nieobecny, to jego sprawa generuje określone reakcje, postawy, eskaluje konflikt w społeczeństwie francuskim. Obydwa fragmenty stanowią wypowiedziany z różną intensywnością „komentarz do epoki”, zarówno tej odchodzącej wraz z końcem wieku, jak i tej nadchodzącej, której złe korzenie dopiero się odsłaniają.

Zagraniczne tytuły nakręconego we Francji filmu Romana Polańskiego J'accuse (2019) nie są literalnym przekładem tego oryginalnego na angielski, włoski, hiszpański czy polski i zamiast Oskarżam, brzmią: Oficer i szpieg (An Officer and a Spy, L'ufficiale e la spia, El oficial y el ospa), co stanowi nawiązanie, czy raczej po prostu przejęcie, tytułu powieści Roberta Harrisa ${ }^{3}$, stanowiącej podstawę literacką scenariusza. Wyjątek od tej translacyjnej reguły uczynili niemieccy dystrybutorzy, nadając filmowi tytuł Intrige (Intryga). W ślad za tym odstępstwem poszli twórcy plakatu (a także okładek płyt DVD i Blue-Ray z J'Accuse), wykorzystując na nich fotos pokazujący stojących naprzeciwko siebie głównych protagonistów: pułkownika Marie-Georgesa Picquarta (Jean Dujardin) i kapitana Alfreda Dreyfusa (Louis Garrel). Przywołuje on scenę spotkania obu oficerów (jest to właściwie obraz pierwszego retrospektywnego wspomnienia Picquarta) na korytarzu akademii wojskowej. Dreyfus zatrzymuje w niej przełożonego (w filmie stoją w odwrotnej kolejności niż na plakacie), by zapytać, czy zaniżona (w jego przekonaniu) ocena, jaką otrzymał od Picquarta na

\footnotetext{
1 „Najważniejszym pojedynczym elementem filmu jest scena. To jest miejsce, gdzie dzieje się coś konkretnego i określonego. Scena tworzy jednostkę akcji, poprzez którą opowiada się fabułę. Długość scen może być dowolna. W filmie może to być jedno ujęcie, może to być także kilka ujęć. Scena wiąże się nie tylko z miejscem, ale (...) także z czasem. Nie sposób zbudować prawidłowo sceny nie znając jej miejsca i czasu. W filmie mamy do czynienia z trzema rodzajami scen: scena akcji, scena dialogowa i scena mieszająca akcję z dialogiem. Wszystko, co dzieje się w filmie, dzieje się w scenach. Właśnie w scenach opowiada się fabułę" (Kluba 2001, 44).

2 „W porównaniu ze sceną - sekwencja jest całością bardziej skomplikowaną. Można ją określić, że przedstawia sobą serię scen, połączonych jedną myślą, jak: wesele, pogrzeb, wyścigi, zebranie, przyjazd lub odjazd, napad na bank itd. Sceny włączone do sekwencji dzieją się w różnych miejscach i w różnym czasie. Nie jest ona «kolekcją» pełnych scen, lecz tylko ich fragmentów. Chociaż wyjątki nie są wykluczone. Sekwencja tworzy pełną i zamkniętą jednostkę akcji dramatycznej, którą ożywia jedna idea. Podobnie jak scena - sekwencja musi mieć swoje uczłonowanie: początek (ekspozycję), środek (rozwinięcie z «momentem szczytowym») i koniec"(Kluba 2001, 49).

3 „Książka ta, choć utrzymana w konwencji powieści, opowiada prawdziwą historię sprawy Dreyfusa - zapewne największego skandalu politycznego oraz największej pomyłki sądowej w historii, którymi w latach dziewięćdziesiątych XIX wieku najpierw żyła Francja, a w końcu pasjonował się cały świat. Afera wybuchła zaledwie dwadzieścia pięć lat po tym, jak Niemcy rozgromili Francuzów w wojnie z roku 1870 i zajęli terytoria Alzacji i Lotaryngii - to trzęsienie ziemi zakłóciło europejską równowagę sił i dało podwaliny zarówno pierwszej, jak i drugiej wojnie światowej” (Harris 2020, 7).
} 
egzaminie, wynika z uprzedzeń, jakie ten żywi wobec Żydów. Przyszły pułkownik zaprzecza.

Zapewne wbrew intencjom zagranicznych dystrybutorów, którzy nadali filmowi bardziej chwytliwy tytuł od oryginalnego, a potem niejako konsekwentnie posłużyli się pasującym do niego wizualnym motywem ${ }^{4}$, tak anonsowany utwór od pierwszego kontaktu z dziełem stawia Dreyfusa w pozycji szpiega bardziej niż ofiary intrygi (ku niej kieruje uwagę niemiecki tytuł) francuskich oficerów, niekryjących swych antysemickich uprzedzeń. Mniejsza o to, jak tytuł Oficer i szpieg ma się do powieści, będącej bardziej niż film wielowątkową, rozbudowaną i zniuansowaną narracją o losach dwóch żołnierzy, niesłusznie oskarżonego o szpiegostwo kapitana armii francuskiej i nowego szefa kontrwywiadu Sztabu Generalnego, który dąży do uwolnienia i uniewinnienia Dreyfusa. J'accuse (Oskarżam) Polańskiego stanowi oczywiste (bo wyjaśnione w toku filmowej opowieści) nawiązanie do tytułu słynnego artykułu Emila Zoli (będącego listem otwartym pisarza do prezydenta republiki Félixa Faure’a), który ukazał się 13 stycznia 1898 roku na łamach dziennika L'Aurore. Publikacja stanowiła punkt zwrotny w aferze Dreyfusa. Jej autor w sposób dobitny sformułował oskarżenia wobec konkretnych osób, wyższych dowódców i biegłych sądowych, którzy doprowadzili do oskarżenia o szpiegostwo, postawienia przed sądem i skazania na podstawie fałszywych dowodów oficera artylerii Alfreda Dreyfusa ${ }^{5}$. Efekt działania publikacji Zoli został pokazany w jednej z kluczowych dla wymowy filmu sekwencji, do której jeszcze powrócę.

Polański mógł zatytułować swój film Afera Dreyfusa zgodnie z tym, o czym opowiada. Wszak utwór ten jest zwartą rekonstrukcją kluczowych wydarzeń związanych z jedną z najbardziej znanych afer końca XIX wieku, wymienianych w hasłach encyklopedycznych przy nazwisku Alfreda Dreyfusa. Byłby w tym bliski swoim poprzednikom, którzy wcześniej sięgnęli po temat słynnej afery, przenosząc go na kinowe i telewizyjne ekrany ${ }^{6}$. Już w 1899 roku wielki pionier kina, Georges Méliès, nakręcił Sprawe Dreyfusa (1899), pokazywaną dzisiaj w Internecie jako kilkunastominutowy film niemy (w istocie jest to składanka jedenastu krótkich filmów7),

\footnotetext{
${ }^{4}$ Fotos z filmu przedstawiajacy obu oficerów naprzeciwko siebie został wykorzystany nim film trafił na ekrany na okładce wznowionego polskiego wydania powieści Roberta Harrisa Oficer i szpieg.

5 „Za sprawą Zoli i jego J'accuse...! Alfred Dreyfus z ofiary pomyłki sądowej przeobraził się w symbol człowieka, przeciw któremu skierowany został aparat państwa. Opowieść o niesłusznym skazaniu stała się obrazem ludzkiej krzywdy, sprowadzonej na niewinnego, szlachetnego oficera przez cynizm i podłość politycznych oraz wojskowych decydentów" (Budzanowska, Pietrzykowski 2020, 35).

6 Zob. Thomas Doherty, From Méliès to Polanski: The Dreyfus Affair of Film (Preview), https://www.cineaste.com/fall2020/melies-polanski-dreyfus-affair-on-film (dostęp: 12.11.2020).

7 „Ściśle rzecz biorąc, Sprawa Dreyfusa była cyklem jedenastu filmów, bo to był jeszcze okres utworów minutowych. Już kompozycja cyklu zdaje sprawę z jego dramaturgicznej otwartości: 1 . Dyktando (Aresztowanie Dreyfusa); 2. Uwięzienie na Wyspie Diabelskiej; 3. Zakucie w kajdany; 4. Samobójstwo pułkownika Henry'ego; 5. Wyjście Dreyfusa na brzeg w Quiberon; 6. Widzenie z żona; 7. Zamach na mecenasa Labori; 8. Walka dziennikarzy; 9. Sad wojskowy w Renes; 10. Degradacja Dreyfusa; 11. Dreyfus odprowadzony z liceum $w$ Renes do więzienia. Sposób odtworzenia zdarzeń nie pozostawiał wątpliwości, że autor jest po stronie Dreyfusa, co podkreślała decyzja obsadowa: Méliès, tak lubiący role diabelskie, zagrał tym razem adwokata oskarżonego, mecenasa Tabori, który padł ofiarą prawicowego zamachu. Poza teatrem Mélièsa, we Francji praktycznie nie pokazywano Sprawy Dreyfusa; jarmarczni dystrybutorzy nie chcieli zrażać swej ludowej publiczności" (Lubelski 2009, 127-128).
} 
a blisko sto lat później Yvess Boisset zatytułował tak samo L'affaire Dreyfus (1995) trwający blisko trzy i pół godziny telewizyjny film fabularny. W epoce wczesnego kina dźwiękowego, ale jeszcze przed wybuchem II wojny światowej, nakręcono dwa obrazy pod tytułem Dreyfus - pierwszy wyreżyserowany przez Richarda Oswalda w 1930 roku oraz drugi, podpisany przez F. W Kraemera i Miltona Rosmera, z 1931 roku. Sześć lat później William Dieterle nakręcił w Hollywood Życie Emila Zoli (1937), obraz podejmujący tę samą tematykę, co wymienione filmy. Jednak żaden z nich, podobnie jak nakręcone w kolejnych dekadach tytuły (Oskarżam!, 1958, reż. José Ferrer, Więźniowie honoru, 1991, reż. Ken Russell), nie zyskał rangi artystycznej dzieła wybitnego. Dla Romana Polańskiego mogło to stanowić jeden z powodów, dla którego uznał, że sprawa Dreyfusa stanowi wielki temat dla kina, wciąż niepokazany na miarę możliwości sztuki filmowej.

Oficer i szpieg (by jednak pozostać przy tytule, pod jakim film jest pokazywany), wyszedł spod ręki reżysera, który przeżył Holokaust i stracił w nim członków swojej rodziny (jego matka zginęła w Auschwitz, takjak Madeleine Lévy, wnuczka Dreyfusa), twórcy Pianisty (2002), adaptacji wspomnień ocalałego z Zagłady pianisty i kompozytora - Władysława Szpilmana. Fakty te nabierają szczególnego znaczenia w kontekście podjętego w filmie tematu antysemityzmu i jego niszczącej siły. Chodzi tu zarówno o pokazanie dramatu niewinnie skazanego kapitana Dreyfusa, jak i mechanizmów działania systemu władzy w dziewiętnastowiecznej Francji ${ }^{8}$ - i szerzej Europie - opartych na poglądach głęboko zakorzenionych w ówczesnych społeczeństwach kontynentu, który kilkanaście lat po opisanych w filmie wydarzeniach stał się areną najkrwawszej z dotychczasowych wojen, poprzedzającej hekatombę jeszcze większych rozmiarów.

Jürgen Osterhammel w rozdziale „Cywilizowanie” $i$ wykluczanie ze swej monumentalnej Historii XIX wieku pisał:

Po mniej więcej 1870 r. w prawie całej Europie polemika z Żydami znów przybrała na sile. Przeciwnicy Żydów przeszli do ataku. Przede wszystkim we Francji i Niemczech nie zrezygnowano wprawdzie całkowicie ze starego teologicznego obrazu Żyda, ale uzupełniono go teraz argumentacjami świecko-racjonalistycznymi. Oskarżenia przeciwko Żydom jako protagonistom i beneficjentom irytującej nowoczesności przybrały postać teorii spiskowych. Do zarzutu niższości moralnej doszedł z nacjonalistycznego punktu widzenia zarzut nielojalności. Pod wpływem nowego biologizującego myślenia Żydzi byli w coraz większym stopniu konstruowani jako odrębna „rasa”. Ten, kto myślał i pisał, chciał powiedzieć, że żydowska asymilacja to tylko manewr pozorny, że indywidualne przechodzenie na chrześcijaństwo nie ma znaczenia i że Żydzi nigdy się nie zmienią (Osterhammel 2013, 1144).

Fragmenty wybranych scen i dialogów z Oficera i szpiega mogłyby stanowić ilustrację powyższych słów. Polański - za autorem powieści, na

\footnotetext{
${ }^{8}$,Antysemityzm francuski, któremu w niemałym stopniu wystarczała sama świadomość istnienia Żydów, bez konieczności kontaktu fizycznego, intensyfikował się od początku lat osiemdziesiątych XIX wieku. W odniesieniu do ówczesnej Francji można wyróżnić sześć jego odmian". Dalej autor wymienia i omawia pokrótce antysemityzm ekonomiczny, lewicowy, rasowy, seksualny, katolicki i nacjonalistyczny (Horoszewicz 2017, 31).
} 
podstawie której powstał scenariusz - uczynił protagonistą pułkownika Marie-Georgesa Picquarta, oficera, który ujawnił bezpodstawność oskarżeń, w wyniku których skazano Dreyfusa. W filmie oglądamy ewolucję jego postawy, w miarę jak odkrywa, że do zdrady, o której był początkowo przekonany, nigdy nie doszło, a samo oskarżenie i skazanie niewinnej ofiary wynikają wyłącznie z antysemickich uprzedzeń wyższych oficerów armii wobec jedynego wśród nich Francuza żydowskiego pochodzenia. Zresztą sam Picquart żywi podobne, pełne uprzedzeń przekonania wobec Żydów, przynajmniej do momentu odkrycia przez siebie prawdy o bezpodstawności oskarżeń wymierzonych w jego byłego ucznia. Istotę tego sposobu myślenia o świecie stanowi - zgodnie z tym, co pisze Osterhammel - traktowanie antysemickiej argumentacji jako naturalnej, całkowicie zasadnej i racjonalnej. W pewnym sensie - jak pokazano w filmie - żydowskie pochodzenie Dreyfusa stanowi dla oficerów prowadzących śledztwo pierwszy i niepodważalny dowód zdrady kapitana artylerii.

W otwierającej film scenie publicznej degradacji Dreyfusa, będącej $\mathrm{w}$ istotnej mierze rodzajem „dokumentalnej rekonstrukcji” historycznych wydarzeń, Picquart obserwuje całe zdarzenie (ów armijny ceremoniał zdzierania dystynkcji i epoletów, łamania szabli oficerskiej), niejako z bliska, bo przez lornetkę . Stojący obok niego major Hubert-Joseph Henry (oficer kontrwywiadu, który sfałszował dowody przeciwko Dreyfusowi, w tej roli Grégory Gadebois) rzuca w stronę majora pytanie: „Jak on wygląda, Picquart?" ${ }^{10}$. Odpowiedź, której udziela, nie pozostawia wątpliwości co do jego zapatrywań: „Jak żydowski krawiec opłakujący złoto ze swoich naszywek". Słowa Picquarta wywołują śmiech u pułkownika Jeana Sandherrera (Eric Ruf), szefa Sekcji Statystycznej (taką nazwę nosi komórka kontrwywiadu francuskiego Sztabu Generalnego). Chwilę później (po tym, jak szabla Dreyfusa zostanie złamana, a on sam idąc w asyście żołnierzy, krzyczy w stronę rozwścieczonego tłumu: „Jestem niewinny”!) odpowiada Picquartowi: „Rzymianie rzucali lwom chrześcijan, a my Żydów. To chyba jakiś postęp, co?”. W ten sposób poznajemy poglądy francuskich oficerów piastujących wysokie funkcje $\mathrm{w}$ armii, ale także sam temat antysemityzmu zostaje zasygnalizowany już na początku filmu jako kluczowy w utworze.

Scena otwierająca film opatrzona została napisem „Wszystkie postacie i wydarzenia w tym filmie są prawdziwe” oraz informacją o dacie ukazanych wydarzeń: „5 stycznia 1895 roku”. Rozpoczyna ją szeroki, ogólny plan, w którym widoczne w oddali sylwetki żołnierzy ustawionych w szeregu zaledwie podkreślają przytłaczający ogrom paryskiego placu i otaczających go budowli. Początek tego ujęcia może kojarzyć się z pierwszymi filmami braci Lumière. Przede wszystkim za sprawą jego formy, ale warto też zauważyć, że wydarzenia pokazane w tej scenie miały miejsce w roku

${ }^{9}$ Film w wersji, z której korzystałem przy pisaniu artykułu, wydanej na DVD przez Gutek Film, trwa 126 minut.

${ }^{10}$ Wszystkie cytaty z filmu podaję w tłumaczeniu z opublikowanej na DVD wersji filmu. Napisy opracował do niej Piotr Kamiński. 
uznanym za datę narodzin kina. Gdyby nie kolor i powolny ruch panoramującej w lewo kamery (zaczynający się po 30 sekundach), moglibyśmy wręcz uznać początkowy fragment Oficera i szpiega za pastisz któregoś z filmów nakręconych przez wynalazców kinematografu (trwały one 50 sekund, były czarno-białe, kręcono je nieruchomą kamerą ze statywu). Jednak bardziej oczywistym nawiązaniem do wczesnych filmów (jeśli doszukiwać się ich w pierwszej scenie Oficera i szpiega) jest to odnoszące się do wspomnianych krótkich filmów Georgesa Mélièsa o wydarzeniach związanych $\mathrm{z}$ aferą Dreyfusa.

Inscenizując omawianą scenę, Polański korzystał - jak można się domyślać - z inspiracji rysunkami zamieszczanymi we francuskiej prasie na początku 1895 roku. Wystarczy ją porównać z dwiema ilustracjami: opublikowaną w „ĹIllustration” 12 stycznia ${ }^{11}$ oraz inną, z okładki „Le Petit Journal" z 13 marca 1895 roku, autorstwa Henri Meyera, opatrzonej podpisem „Zdrajca”. Widać na nich kirasjera łamiącego na kolanie szablę przed stojącym na baczność Dreyfusem, a w tle innego oficera na koniu, żołnierzy za plecami degradowanego i budynki akademii wojskowej. Wszystko to zostało pokazane w pierwszej scenie filmu Polańskiego.

Nawiązania do rysunków z epoki można odnaleźć także w późniejszych fragmentach filmu. Weźmy choćby scenę postrzelenia mecenasa Fernanda Laboriego (Melvil Poupauld). Jej inscenizacja bardzo przypomina rysunek zamieszczony w numerze „Le Petit Journal” z 27 sierpnia 1899 roku (zob. Horoszewicz 2017, 197). Widać na nim trzech mężczyzn w kapeluszach z laseczkami w dłoniach, którzy właśnie zastygli, uchwyceni w dramatycznym momencie. Fernand Labori wygina się w sposób nienaturalny do przodu rażony kulą zamachowca, który owiany chmurą prochowego dymu stoi kilka kroków za nim. Idący obok Laboriego Picquart (po lewej) i Edmund Gast (po prawej) stają jak wryci, zwróceni twarzami w stronę ranionego towarzysza. W Oficerze i szpiegu scena ta została sfilmowana w bardzo podobny sposób. Nawet pejzaż jest ten sam - z dróżką otoczoną karłowatymi drzewami o drobnych koronach, ledwo pokrytych liśćmi na krótkich gałęziach. Kamera pokazuje idących w jej kierunku trzech mężczyzn (w tym samym układzie: Picquart, Labori i Gast). Za ich plecami zjawia się zamachowiec. Podbiega niezauważony i z bliskiej odległości oddaje strzał w plecy Laboriego, który wygina się jak postać na rysunku z „Le Petit Journal". Dalej oglądamy wydarzenia, których rysownik nie zdołał uchwycić na jednym obrazie - upadek ciężko ranionego adwokata i pościg Picquarta za zamachowcem.

Wróćmy jeszcze do początku filmu i samego Picquarta. Jego antysemityzm wyraźnie wybrzmiewa nie tylko na placu, gdzie degradowany jest Dreyfus, ale także w dwóch innych scenach. W drugiej z kolei (w filmie) major składa raport przed ministrem wojny, generałem Augustem Mercierem (Wladimir Yordanoff) i stojącym obok generałem Raoulem le Mouton de

${ }^{11}$ Ilustracja przedrukowana w: Horoszewicz 2017, 45. 
Boisdeffre (Didier Sandre). Pada pytanie z ich strony: „W jakim nastroju to się skończyło?”. Picquart (jakby dopowiadając do tego, co już powiedział majorowi Henry'emu, gdy określił degradowanego mianem „żydowskiego krawca opłakującego złoto ze swoich naszywek”) odpowiada: „Jakby zdrowe ciało pozbyło się zarazy i życie zaczęło się od nowa".

W kolejnej krótkiej scenie oglądamy Dreyfusa w więzieniu na Diabelskiej Wyspie, miejscu jego zesłania. Po czym, dla kontrastu, zostajemy przeniesieni w sielankowy pejzaż z Picquartem, odpoczywającym w gronie przyjaciół na łonie natury (scena budzi skojarzenia z obrazem Śniadanie na trawie, Claude'a Moneta z 1865 roku). Powraca temat antysemityzmu, ale tym razem $w$ rozmowie pada zdanie kluczowe dla przemiany, jaka dokona się $\mathrm{w}$ Picquarcie. Jeden $\mathrm{z}$ biesiadujących na kocu rzuca pytanie $\mathrm{w}$ kierunku mężczyzny z cygarem, który czyta gazetę (z widocznym na pierwszej stronie dużym nagłówkiem: Dreyfus a L'ile du Diable): „Wciąż piszą o tym Żydzie?". Ten, zamiast udzielić odpowiedzi, kieruje swe słowa do pułkownika: „Picquart! Pan go znał, prawda? - Słucham? Kogo? - Dreyfusa. - Tak, był moim uczniem”. Mężczyzna, który rozpoczął rozmowę, dopytuje: "Czy go pokrzywdzono, bo to Żyd?". Do rozmowy włącza się mecenas Louis Leblous (Vincent Perez): „Oczywiście. Jako adwokat, mogę cię zapewnić, że katolik miałby należyty proces”. Mężczyzna z cygarem znów zwraca się do oficera: „To prawda, Picquart?”. Ten: „Nie miał należytego procesu, mój drogi, bo kwestii bezpieczeństwa państwowego nie można omawiać publicznie. Ale dowodów było pod dostatkiem, wierz mi". Słuchający tych słów adwokat w milczeniu kiwa przecząco głową. Odpowiedź, której udzielił Picquart, widocznie nie zadowala nawet jego samego. Odtąd zacznie się u niego proces analizowania przeszłych wydarzeń. Odkrywając nowe sekrety związane z aferą Dreyfusa, będzie badał wydarzenia z jej początku, w których sam brał udział, odkrywając teraz krok po kroku fałszerstwo i co do niego doprowadziło.

Pierwszy obraz, który Picquart wywołuje z pamięci, dotyczy wspomnianej sceny spotkania z Dreyfusem na korytarzu akademii wojskowej. Warto przywołać rozmowę oficerów, bo w niej trzeci już raz z kolei (licząc od początku filmu) major wyraża swoją niechęć wobec Żydów. Dreyfus woła za odchodzącym Picquartem: „Panie majorze!” Picquart staje i odwraca się, „Tak, kapitanie?”. Dreyfus podchodzi i teraz obaj stoją zwróceni do siebie twarzami, a profilami do kamery. Dreyfus: „Panie majorze. Czy jakoś pana uraziłem?” Picquart „Nie”. Rusza korytarzem, a Dreyfus za nim: "Żaden wykładowca tak źle mnie nie ocenił”. Picquart: „Może nie cenię pańskich zdolności równie wysoko jak pan”. Dreyfus: „Nie dlatego, że jestem Żydem?” Picquart: „Dbam, by moje uprzedzenia nie wpływały na moje oceny”. Dreyfus: „Skoro musi pan o to dbać, to dopuszczalna hipoteza”. Mężczyźni znów zatrzymują się i stają naprzeciw siebie. Picquart: „Jeśli pyta pan, czy lubię Żydów, uczciwie odpowiem, że nie. Ale jeśli pan 
sugeruje, że przez to szykanuję pana w płaszczyźnie zawodowej, zapewniam, że bynajmniej. To wykluczone". Dreyfus pręży się w postawie oficerskiej, lekko kłania i odchodzi w głąb korytarza. W finale filmu oficerowie spotykają się po raz ostatni (scena ta stanowi jakby rewers opisanej powyżej). Dreyfus został uniewinniony i przywrócony w szeregi armii, Picquart awansował na generała i został ministrem wojny. Wymowa sceny jest oczywista - sprawiedliwość zatriumfowała, a Picquart jest jak najdalszy od swych dawnych uprzedzeń, choć armia znów potraktowała obu oficerów w różny sposób. Picquartowi zaliczono do służby lata, gdy był wydalony z armii (w związku ze sprawą), ale Dreyfusowi - już nie. Major domaga się od Picquarta sprawiedliwego potraktowania w sprawie awansu, ale minister nie przychyla się do jego prośby. Sytuacja polityczna we Francji znów się zmieniła i takie zadośćuczynienie Dreyfusowi Picquart uznaje za niemożliwe do spełnienia ${ }^{12}$. Zanim jednak opowieść osiągnie tak „szczęśliwy” finał, oglądamy Picquarta w sytuacjach wyraźnie demonstrujących motywowane antysemickimi przekonaniami działania wyższych oficerów i stronniczo zaangażowanych w sprawę grafologów.

I tak, kiedy już jako oficer kontrwywiadu Picquart wraca pamięcią do wydarzeń poprzedzających aresztowanie Dreyfusa, przypomina sobie moment, w którym poprzedni dowódca Sekcji Statystycznej, major Sandherrer, zażądał wglądu w teczki podopiecznych Picquarta, szukając oficera, który wysłał do ambasady Niemiec list z propozycją podjęcia współpracy wywiadowczej ${ }^{13}$. Ale zamiast przejrzeć zawartość każdej z nich, by porównać charaktery pism wszystkich oficerów z przechwyconym bordereau poszukiwanego zdrajcy, wybiera od razu teczkę Dreyfusa, gdy tylko orientuje się, że jest on jedynym w tym gronie Żydem. Natychmiast też doszukuje się podobieństw między jego charakterem pisma a tym, jakim napisano kompromitujące dokumenty. Później tym samym tropem podąży obecny na procesie Dreyfusa biegły grafolog, Alphonse Bertillon, tłumacząc

\footnotetext{
${ }^{12}$ Najważniejszy fragment rozmowy brzmi tak: Generał Picquart: „O czym pan pragnął porozmawiać?” Major Dreyfus: „O mojej randze. Nie wzięto pod uwagę lat bezprawnego pozbawienia wolności. Pański awans, proszę wybaczyć, że wspominam, uznaje osiem lat poza armią za lata służby czynnej. To niesprawiedliwe. A nawet krzywdzące.” Picquart: „Rozumiem. Co mam zrobić w takim razie?” Dreyfus: „Dać mi rangę, która mi się należy”. Picquart: „Jaką według pana?” Dreyfus: „Podpułkownika”. Picquart: „To by wymagało specjalnej ustawy”. Dreyfus: „I trzeba to zrobić, to byłoby słuszne”. Picquart: „Ale niemożliwe”. Dreyfus: „Ale dlaczego?” Picquart: „Taka ustawa nie przejdzie. Klimat polityczny zmienił się zupełnie. Pracuję z naszymi dawnymi, zapiekłymi wrogami. Musiałbym budzić stare spory”. Dreyfus: „Owszem, bo tak należy”. Picquart: „Przykro mi majorze, nie mogę. Czy to wszystko?” Dreyfus: „Tak, to wszystko”. Picquart: „Żałuję, że przez tyle lat nie mieliśmy okazji porozmawiać prywatnie”. Dreyfus: „To prawda. Ani razu od dnia mojego aresztowania”. Picquart: „Przepraszam za rolę, jaką grałem w tej ponurej farsie”. Dreyfus: „Nadrobił to pan z nawiązką. To wspaniale, że po tym wszystkim został pan ministrem Republiki”. Picquart: „Wie pan, może to zabrzmi dziwnie, ale zawdzięczam to panu”. Dreyfus: „O nie, panie generale. Tylko temu, że spełnił pan swój obowiązek”. Po ściemnieniu na czarnym tle pojawia się napis: „Obaj żołnierze nigdy się więcej nie spotkali".

13 „W 1894 roku do biura attaché wojskowego ambasady niemieckiej w Paryżu, pułkownika Maximiliana von Schwartzkoppena, trafiła notatka zawierająca wykaz tajnych dokumentów dotyczących wyposażenia francuskiego wojska. Notatkę tę, określaną później jako bordereau, udało się przechwycić francuskiemu kontrwywiadowi. Była ona niepodpisana i nieopatrzona datą, a wynikało z niej, że francuski oficer zaproponował Niemcom dostarczenie informacji dotyczących nowego uzbrojenia francuskiej armii, m.in. nowej broni artyleryjskiej oraz dwunastu map fortyfikacji wojskowych w Nicei" (Budzanowska, Pietrzykowski 2020, 15).
} 
wszystkie niepodobieństwa między próbkami pisma na niekorzyść oskarżonego (znaczące jest, że słowo, które wybrał i powiększył, by przeanalizować na jego przykładzie charakter pisma, brzmi „interes”). Pozostaje niezachwiany w swym sposobie myślenia nawet wówczas, gdy Picquart przynosi mu dowody bezsprzecznie dowodzące, że zdrajcą jest major Charles Ferdynand Walsin-Esterhazy (Laurent Natrella) i to jego ręką były pisane szpiegowskie meldunki. Picquart: „A gdybym panu powiedział, że to nie Dreyfus napisał?” Bertillon: „Uznałbym, że najwyraźniej Żydzi wyszkolili kogoś innego, by umiał pisać metodą Dreyfusa".

Wreszcie, gdy Picquart przedstawia generałowi Charles-Arthurowi Gonse'owi (Hervé Pierre) dowód na niewinność Dreyfusa i domaga się wszczęcia nowego procesu, szef wywiadu stanowczo oponuje: „Wykluczone. Bo byśmy całkiem stracili twarz! Nie rozumiem pana. Wiemy, co pan myśli o Narodzie Wybranym. Co panu zależy, że jakiś Żyd siedzi sobie na skale". Picquart: „Zależy mi, bo jest niewinny”. Gonse przez chwilę śmieje się, a potem mówi: „Ależ pan sentymentalny! Jagniątka, kociątka i Dreyfus, same niewiniątka”. Picquart: „Mówi pan, jakbym żywił do niego jakieś uczucia. Skąd! Wolałbym, żeby był winien, byłoby łatwiej. Ale zdrajcą jest Esterhazy”. Gonse: „Może jest, a może nie jest. Milcz pan i nikt się nie dowie”. Picquart: „To obrzydliwa sugestia. Nie mogę z tym iść do grobu”. Gonse: „Może pan. Brać do grobu tajemnice, to nasze powołanie. Nie mam nic do dodania. Dreyfusa mi do tego nie mieszać. To rozkaz".

Wszystkie te przykłady to fragmenty scen i dialogów wybrane, by zarysować istotę wyeksponowanego w filmie konfliktu - między odkrywającym krok po kroku prawdę Picquartem a wyższymi oficerami, zdeterminowanymi zatuszować pomyłkę sądową, której ofiarą padł Dreyfus, ale też przekonanych o niewielkiej cenie, jaką jest ofiara z życia i honoru oficera żydowskiego pochodzenia. Bez zarysowania tego kontekstu wymowa kluczowej dla filmu sekwencji, a także jej estetycznego zakomponowania, byłaby niepełna.

Raz jeszcze powróćmy do oryginalnego tytułu filmu - J'accuse. Kogo lub czego dotyczy wypowiedziane w nim oskarżenie? Aby na to pytanie odpowiedzieć, trzeba przywołać sekwencję, w której oglądamy moment ukazania się artykułu Zoli i serię wydarzeń z tym powiązanych. W dziewięćdziesiątej minucie filmu aresztowany pułkownik Picquart wsiada do konnej karetki więziennej. Powóz rusza. Po chwili mija tłumnie oblegany kiosk z gazetami. Słychać unoszący się nad stłoczonymi okrzyk jednego z biegnących gazeciarzy: „Zwrot w aferze Dreyfusa! Kupujcie L'Aurore! Oskarżam! List Zoli do Prezydenta! Kupujcie L'Aurore!" ${ }^{14}$ Obserwujący ulicę zza krat jadącej więźniarki Picquart przywołuje chłopca. Powóz staje. Pułkownik kupuje gazetę. "Co tam piszą?” - pyta eskortujący go stary oficer. Picquart zaczyna czytać artykuł Emila Zoli: „Jesteśmy świadkami haniebnego widowiska,

${ }^{14}$ O sprawie Dreyfusa i znaczeniu artykułu Zoli zob.: Bieńkowska E., 2019, Spór o dziedzictwo europejskie. Między świętym a świeckim, Warszawa. 
gdzie zadłużony przestępca uchodzi za niewinnego, a poniewiera się honor człowieka bez skazy. Gdy społeczeństwo upada tak nisko, grozi mu zguba”. "- Co za bezczelność." - wyrywa się eskortującemu i bez czytania podaje przekazaną przez Picquarta gazetę drugiemu ze strażników. Rozpostarcie przez niego gazety stanowi gest powielony w kolejnych krótkich scenach pokazujących głównych uczestników afery Dreyfusa, w których celnie wymierzył swe słowa autor Germinal.

Pierwszy pojawia się pułkownik Armand du Paty de Clam (w mundurze i oficerskim kepi na głowie, w tej roli Michel Vuillermoz), który kilka scen wcześniej podał Dreyfusowi rewolwer, licząc, że ten popełni samobójstwo po usłyszeniu oskarżenia o szpiegostwo. Du Paty zatrzymał się na ulicy i właśnie czyta drugą stronę gazety. Widać stronę tytułową L'Aurore z napisanym dużymi literami tytułem J'accuse! Pojawia się muzyka w tle. Posępne akordy łączą kolejne sceny. Zza kadru słychać głos du Paty’ego, jak czyta fragment artykułu: „Oskarżam pułkownika du Paty, piekielnego architekta tej pomyłki sądowej”. Nim wybrzmi ostatni fragment tego zdania, kamera po cięciu przechodzi od zbliżenia do planu ogólnego, by pokazać majora stojącego z rozpostartymi szpaltami gazety na środku zatłoczonej ulicy, mijanego przez ludzi i powóz konny. Kolejny fragment artykułu Zoli także słychać zza kadru, ale tym razem czytany głosem kolejnej postaci, która pojawia się na ekranie. Generał Mercier siedzi przy stole na tle okna w swoim mieszkaniu. Czyta gazetę przy śniadaniu. Tu także widać tytuł na pierwszej stronie, jakby wyłaniający się zza srebrnej zastawy na pierwszym planie. Słyszymy: „Oskarżam generała Merciera o współudział bodaj na tle niedowładu umysłowego $\mathrm{w}$ największej nieprawości stulecia”. Na dźwięk ostatnich słów generał upuszcza trzymaną w dłoni filiżankę. Kamera, jak poprzednio po cięciu, przechodzi do szerszego planu, by ukazać długi stół, przy którym śniada generał, i stojącego obok niego kamerdynera. I kolejna postać w krótkiej scenie - generał Jean-Baptiste Billot (Vincent Grass) bez koszuli i płachta L'Aurore. Zza kadru jego głosem: „Oskarżam generała Billota, który posiadając dowody niewinności Dreyfusa, zataił je, dopuszczając się zbrodni przeciwko człowieczeństwu i sprawiedliwości (tu następuje przeskok do ujęcia w planie ogólnym pokazującego, że oficer czyta w wannie - przyp. M.J.) z pobudek politycznych, by ocalić skompromitowany sztab".

Od momentu upuszczenia filiżanki przez Merciera, przez pokazanie gołego Billota w kąpieli, potęguje się dyskretnie zaznaczony komizm sytuacyjny, którego kulminacja przychodzi w kolejnej scenie. Tym razem pogrążonym w lekturze oficerem jest Georges Gabriel de Pellieux (Laurent Stocker), który czyta tekst Zoli, siedząc na koniu, gdzieś w parku. Zgodnie z obecną już w poprzednich scenach regułą łączenia bliskich planów z szerszymi ujawniającymi kontekst „czytelniczego doświadczenia”, tu także po chwili widzimy Pellieux z oddalenia. Siedzi na białym koniu, a stający obok oficer trzyma za uzdę innego kasztanowatego wierzchowca. Wyraźnie cały 
drży, gdy czyta (swoim głosem zza kadru): „Oskarżam generała de Pellieux o monstrualną stronniczość $\mathrm{w}$ podłym dochodzeniu, z którego raport stanowi nieśmiertelny pomnik prostodusznej buty". Kolejna scena i następna skompromitowana postać - paryskiego grafologa, Bertillona. Za jego plecami, ponad płachtą gazety widać ludzki szkielet ustawiony w gabinecie: „Oskarżam biegłych grafologów, autorów kłamliwych, nierzetelnych ekspertyz, chyba że medycyna wykaże u nich upośledzenie wzroku i umysłu". Jakby na ostatnie słowa grafolog zgniata gazetę. Oglądamy to z oddalenia, dopiero teraz mając możliwość zobaczenia w całej krasie wnętrza pracowni i dwóch mężczyzn w białych kitlach przy biurku grafologa.

Następne postacie pokazane zostały, jak czytają głośno inne fragmenty artykułu. Zza pleców dwóch generałów widać tekst z drugiej strony gazety. Czyta Gonse: „Oskarżam generałów Boisdeffre’a i Gonse’a o wspólnictwo w tej zbrodni. Pierwszego na tle klerykalizmu...". Na moment milknie. Oficerowie spoglądają na siebie. Kolejny szeroki plan pokazuje ich drobne sylwetki jakby pomniejszone, zredukowane do wymiaru innych przedmiotów z wystroju w ciemnym wnętrzu ministerialnego gabinetu. Gonse czyta dalej: „...drugiego na tle korporacyjnej zmowy, która z jego kasty czyni ciało święte i nietykalne". Ostatni z grona tych, w których mierzy swymi słowami Zola, pojawia się major Henry. Czyta słowa Zoli na głos swym podwładnym na korytarzu Sekcji Statystycznej, w której gabinetach spreparowano fałszywe dowody przeciw Dreyfusowi: „Oskarżam sąd wojenny o pogwałcenie prawa, gdyż skazał obwinionego na mocy tajnych dowodów. I oskarżam drugi sąd wojenny, który ukrył ten akt bezprawia, uniewinniając świadomie winnego człowieka. Narażam się tym na postępowanie karne na mocy artykułów 30 i 31 ustawy z 29 lipca 1881 roku przewidujących karę za zniesławienie. Czynię to dobrowolnie i świadomie". Tym razem kamera wykonuje odjazd do planu pełnego, a dopiero potem po cięciu następuje przeskok do planu ogólnego, tworząc wrażenie, jakby sylwetki czytających nagle zmalały. Za każdym razem daje to efekt podobny do wypuszczania powietrza $z$ balonu. Nadęte persony pokazywane na początku każdej z krótkich scenek w planie bliskim, wyolbrzymiającym ich popiersia do granic ram kadru, gwałtownie kurczą się do wymiarów drobnych figurek w ukazanej w szerokim planie przestrzeni. Jakby słowa Zoli wywoływały efekt przebicia pękatego balonu, który nagle kurczy się, wypuszczając wypełniające go powietrze.

Ostatni fragment opisywanej sekwencji pokazuje uliczne zamieszki wywołane artykułem Zoli: płomienie liżą wydania L'Aurore i stronice powieści Zoli (widać stronę tytułową Nany), zebrany przy wielkim ognisku paryski tłum wrzuca do ognia książki. Jeden z mężczyzna maluje białą farbą gwiazdy Dawida na szybach wystawowych żydowskiego sklepu z jedwabiami i perkalami (widać napis z nazwiskiem Goldman na wejściu), pełen wściekłości tłum (kamera pokazuje oświetlone ogniem twarze) wykrzykuje 
„Śmierć Zoli!” i rozbija kamieniami witrynę sklepową z namalowanym napisem „Śmierć Żydom”. Nad ranem ulica pustoszeje, a ogień w spopielonych książkach dogasa.

Polański tą krótką sceną, wieńczącą całą sekwencję, w kilku zaledwie sugestywnych ujęciach odmalowuje na ekranie w sposób skondensowany cały szereg historycznych zdarzeń, zdetonowanych publikacją Zoli. Michał Horoszewicz tak je opisuje:

Wstydliwą kartę stanowią zamieszki antyżydowskie w 1898 roku. Wiadomo było o demonstracjach paryskich po pierwszym procesie Zoli - zresztą w stolicy pomysłowo założono agencję wynajmującą zawodowych podżegaczy (na cały dzień lub tylko na wieczór) do podtrzymywania napięcia ulicznego przez wznoszenie stosownych okrzyków w rodzaju: «Precz z Żydami! Pluję na Zolę!» - ale ich zasięg był znacznie szerszy. I to, jak stwierdza Wilson [Stephen Wilson - autor książki Ideology and Experience: Anti-Semitism in France at the Time of the Dreyfus Affair - przyp. M.J.], niemal całkowicie przemilczają historycy Sprawy. Rozruchy pogromowe ogarnęły wiele departamentów, zwłaszcza śródziemnomorskich i wschodnich; trwały nierzadko po sześć dni (siedem - w przypadku Paryża). Sprawcami były niekiedy grupy pijanych poborowych, kiedy indziej parotysięczne tłumy z udziałem studentów, handlarzy, pracowników najemnych, czasem kupców. Wznoszono okrzyki na rzecz armii i przeciw Zoli, ale też «Śmierć Żydom - zabić Żydów», wybijano szyby w budynkach żydowskich, plądrowano sklepy żydowskie, atakowano synagogi oraz domy rabinackie. W Paryżu 11 lutego około tysiąca demonstrantów pikietowało dom Dreyfusa. Wojsko zachowywało postawę życzliwą, do rozpraszania używano sił policyjnych; zatrzymano wieleset osób (w Marsylii i Bordeaux ponad setkę, w Paryżu ponad dwie setki). Detonatorem było ogłoszenie listu J’accuse. W kilku miastach doszło do spalenia in effigie Dreyfusa, Zoli i miejscowego rabina. Inspirującego wsparcia udzielali różni aktywiści antysemiccy, na afiszach, podczas zebrań i przemówień, ponadto lokalna prasa, a w niektórych przypadkach organizacje katolickie. (...) W kilku departamentach kolportowano wykazy Żydów z zawodami i adresami. Zaczęły też krążyć destabilizujące pogłoski o nieuchronnej wojnie z Niemcami, w wielu miejscach pojawiły się antysemickie plakaty z napisem: «Ojczyzna w niebezpieczeństwie». Przelew krwi był ograniczony, ale ludność żydowską sterroryzowano. Pogromy w kilku miastach Algierii, przede wszystkim w samym Algierze, były dotkliwsze: doliczono się kilkudziesięciu (50?) zabitych i wielu rannych, całe ulice ze sklepami w dzielnicy żydowskiej ograbiono, synagogi zbezczeszczono. I to tam właśnie powstała piosenka przewidująca wysłanie Żydów na Madagaskar, co tylekroć poważnie rozważano czterdzieści lat później (Horoszewicz 2017, 61-62).

Z punktu widzenia pokazanej w filmie historii fałszywego oskarżenia i osądzenia Dreyfusa opisana powyżej sekwencja krótkich scen (trwająca niecałe trzy i pół minuty) ukazuje istotny punkt zwrotny w aferze i samej filmowej opowieści. Rozgrywana w zaciszu gabinetów wojskowych sprawa staje się odtąd publiczną z wszystkimi tego konsekwencjami ${ }^{15}$. Jednak

\footnotetext{
15 „J'accuse...! Emile’a Zoli przyczyniło się do wielkiego przełomu. Rozgłos artykułu był ogromny, a jego echo słyszalne i odczuwalne jest nadal. Tak jak przewidział pisarz - wywołał w Paryżu burzę i doprowadził do przemiany rzeczywistości społecznej we Francji. Jednym prasowym artykułem Zola, podobnie jak ponad sto lat wcześniej Wolter Traktatem o tolerancji, wszedł do kanonu symboli zaangażowania intelektualistów w sprawy społeczne w imię wartości najwyższych. Sprawa Dreyfusa, którą zrazu interesowała się grupka osób, nabrała pełnego rozgłosu, bowiem przestała sprowa-
} 
odczytywana w szerszym kontekście i w nawiązaniu do tytułu filmu ściśle się do niej odnoszącego ujawnia istotną sugestię czy też przesłanie, wyłożone tu bardzo wyraźnie. Oto wydarzenia rozgrywające się u schyłku dziewiętnastego stulecia na ulicach Francji stanowią jakby zapowiedź tych, które dopiero przyniesie kolejny wiek. Dopowiadając rzecz być może oczywistą - w świetle opisanej powyżej sekwencji - Polański i Paweł Edelman (autor zdjęć do filmu), pokazując sceny palenia książek, malowania gwiazd Dawida na witrynach żydowskich sklepów, a wreszcie rozbijania ich, przywołują obrazy kojarzone z wydarzeniami, jakie (będą) miały miejsce w Niemczech po dojściu Hitlera do władzy. Scena paryskich zamieszek staje się w ten sposób antycypacją przyszłych wydarzeń historycznych, stanowi jakby wyraźne dopowiedzenie aluzji w sposób mniej jawny akcentowanych w całym filmie, szczególnie przez postawę, działania i wypowiedzi osób, które chciały przypieczętować los Dreyfusa, a które w filmie (a w szczególności w przywołanej sekwencji) przedstawił Polański. Jeśli antysemityzm tłumu dosłownie wybucha $\mathrm{w}$ tej scenie, to wcześniej w filmie pokazano pomniejsze jego manifestacje w szeregu działań ludzi na stanowiskach, które doprowadziły do skazania Dreyfusa.

W przeciwieństwie do Roberta Harrisa, autora powieści Oficer i szpieg, Polański w swoim filmie nie objaśnia, skąd wśród wyższych oficerów francuskich tak silne nastroje antysemickie ${ }^{16}$, których ofiarą pada Dreyfus. Bardziej akcentuje potworną „naturalność” oskarżeń kierowanych pod adresem oficera, uzasadniającą każdą podłość, jakiej dopuszczają się jego przełożeni i osoby zaangażowane w skazanie kapitana o żydowskim pochodzeniu. W przeciwieństwie do „jaskrawych” scen z tłumem palącym książki i wypisującym hasła „Śmierć Żydom”, te odsłaniające skrywaną motywację oficerów, sędziów i biegłych sądowych, manifestującą się w konkretnych działaniach w sprawie Dreyfusa, wybrzmiewają mocniej. Przy czym dobór aktorów do ról wysokich rangą oficerów armii francuskiej, zaprezentowanie postaci o wyrazistych twarzach, jakby naznaczonych cynizmem, bezwzględnością i zimnym wyrachowaniem, przywodzi kinomanowi (już w trakcie pierwszego oglądania filmu Polańskiego) skojarzenia ze Ścieżkami chwały (Paths of Glory, 1957) Stanleya Kubricka.

\footnotetext{
dzać się jedynie do kwestii rewizji wyroku wydanego przez trybunał wojskowy wobec żydowskiego oficera, a stała się afera polityczna i wojna o kształt Francji, arena konfliktu masowych ruchów protestu i szańcem obrony wartości republikańskich przeciw fali militaryzmu, nacjonalizmu i antysemityzmu. Pod wpływem tekstu Zoli i w następstwie jego procesu, zatomizowani dotąd zwolennicy obrony republiki, swobód demokratycznych i wolności obywatelskich zjednoczyli się przeciw rosnącym w siłę środowiskom reakcyjnym" (Budzanowska, Pietrzykowski 2020, 38-39).

${ }^{16}$ Picquart, który jest pierwszoosobowym narratorem powieści, wspomina dramatyczne wydarzenia wojny prusko-francuskiej (1870-71), gdy w rezultacie poniesionej klęski zmuszony był, jak wielu innych Francuzów, opuścić rodzinną Alzację. „Poza Bonnierem wszyscy przy stole są wygnańcami z Alzacji i nikt nie powie dobrego słowa o naszym ziomku Alzatczyku, Dreyfusie, nawet Edmund, który jako polityk jest radykalnym republikaninem. Wszyscy mamy za to coś do powiedzenia o Żydach, zwłaszcza z Miluzy, której mieszkańcy, gdy doszło co do czego i po wojnie trzeba było wybierać obywatelstwo, wykazali lojalność wobec Niemców, a nie Francuzów. - Są jak chorągiewki na wietrze, idą za tym, kto akurat jest przy władzy - oświadcza Bonnier, kiwając kieliszkiem wina. - Dzięki temu ich rasa zdołała przeżyć ostatnie dwa tysiące lat. W gruncie rzeczy nie można im mieć tego za złe” (Harris 2020, 39-40).
} 
Dlaczego odniesienie do tego filmu wydaje mi się ważne? Jak już była mowa, Polański obrazami palenia książek i rozbijania witryn sklepowych buduje czytelną aluzję do Holokaustu, pokazując, że sprawa Dreyfusa jest jakby zapowiedzią przyszłego ludobójstwa w Europie, a najpierw Nocy Kryształowej w Niemczech. Wybrzmiewa to w filmie mocno i wyraźnie w jednej krótkiej scenie. Oczywiście, nawet w trwającym ponad dwie godziny filmie fabularnym nie ma miejsca ani sposobu, by taką analogię przedstawić w sposób równie złożony, jak to zrobiła Hannah Arendt w wydanych po raz pierwszy w 1951 roku Korzeniach totalitaryzmu ${ }^{17}$. Poza tym reżyser Pianisty dba o siłę wyrazu poszczególnych scen w filmie, ale także o zachowanie proporcji. Woli - i czyni to w sposób ciekawy - pokazać sprawę Dreyfusa zarówno w kontekście narastającego w Europie, a w szczególności we Francji, antysemityzmu, jak i rosnącej roli militarystów, którzy przyczynią się do wybuchu I wojny światowej (8 lat po rehabilitacji Dreyfusa) i zagłady milionów ofiar na jej frontach. Oficerowie z filmu Polańskiego przypominają z wyglądu i sposobu działania tych z Paths of Glory Kubricka.

Akcja Ścieżek chwały rozgrywa się na froncie wojny światowej, ale ofiarami są tu nie tyle żołnierze ginący na polu bitwy, co „dla przykładu” z rozkazu cynicznych dowódców ${ }^{18}$. Pułkownik Dax (Kirk Douglas), broniący losowo wybranych żołnierzy do rozstrzelania, to jakby pułkownik Picquart w nowej roli. Ta sama armia i ta sama bezduszna machina zawiadywana przez dowódców gotowych poświęcić prawdę i życie niewinnych podwładnych na ołtarzu swych partykularnych celów. To odniesienie to hekatomby pierwszej wojny światowej wybrzmiewa także w oryginalnym tytule filmu Polańskiego. Bowiem J'accuse to tytuł słynnego antywojennego filmu Abla Gance'a $^{19}$ z 1919 roku $^{20}$. Jego reżyser powrócił do tematu, rozwijając go

\footnotetext{
17 „Sprawa Dreyfusa tylko ujawniła ideologiczne i polityczne aspekty wszystkich innych składników dziewiętnastowiecznego antysemityzmu. Była to kulminacja antysemityzmu wyrastającego ze szczególnych warunków stwarzanych przez państwo narodowe. Jednak gwałtowność, z jaką wybuchła ta sprawa, zapowiadała już przyszły rozwój wydarzeń. Odnosi się więc wrażenie, że główni aktorzy sprawy Dreyfusa uczestniczyli w wielkiej próbie generalnej przedstawienia, którego premiere trzeba było odłożyć na ponad trzydzieści lat. Zbiegły się w niej wszystkie, jawne i ukryte, społeczne i polityczne powody, które w XIX w. nadawały kwestii żydowskiej tak wielkie znaczenie. Zarazem jednak ten przedwczesny wybuch sprawił, że francuski antysemityzm utrzymał się w granicach typowej dziewiętnastowiecznej ideologii i mimo że przetrwał wszystkie kryzysy polityczne i rządowe we Francji, nigdy nie potrafił dopasować się do warunków politycznych dwudziestego wieku. Kiedy po porażce w 1940 r. francuski antysemityzm otrzymał wspaniałą szansę pod rządami Vichy, okazał się zdecydowanie przestarzały i mało użyteczny, czego nie zapominali mu nigdy wytknąć nazistowscy komentatorzy z Niemiec. Nie odegrał w każdym razie żadnej roli w powstaniu nazizmu i ma większe znaczenie sam w sobie niż jako czynnik współodpowiedzialny za końcową katastrofę" (Arendt 1989, 83-84).

${ }_{18}$ Tak o filmie Kubricka piszą historycy kina: „Utwór niezwykle krytycznie ukazywał francuską armię oraz mechanizmy podejmowania decyzji przez niekompetentnych i myślących jedynie o własnej karierze dowódców, dlatego nad Sekwaną obowiązywał przez osiemnaście lat zakaz jego wyświetlania. Ale film Kubricka mówił nie tylko o stosunkach panujących w wojsku. Niósł też ogólniejsze przesłanie: o chorobie egoizmu i karierowiczostwa toczącej współczesne, wysoko zorganizowane społeczeństwa. I o ludzkiej bezwzględności w dążeniu do celu” (Plesnar, Syska 2011, 815).

${ }^{19}$ Polański jako student szkoły filmowej spotkał Abla Gance'a w Cannes w 1957 roku w drodze na lotnisko. Tak o tym napisał w swej autobiografii: „Myślałem, że Gance już nie żyje. Czy zdawał sobie sprawę, że w szkole filmowej znaliśmy jego twórczość na pamięć? Podobnie jak filmy René Claira i Jeana Vigo? I że na naszych wykładach z historii filmu przedstawiano go jako jednego z największych nowatorów wszechczasów? Byłem zbyt nieśmiały, by mu o tym powiedzieć" (Polański 1989, 111).

${ }^{20}$ „W Oskarżam melodramatyczna historia zdrady i przebaczenia, wpisana w realia wojny (...), będąca głosem przeciwko wojnie pochłaniającej ofiary (...), została zwieńczona sceną, w której
} 
w formule filmu dźwiękowego z 1938 roku, tak samo zatytułowanego. Zatem oryginalny, francuski tytuł filmu Oficer i szpieg, czyli J'accuse, nawiązuje zarówno do słynnego artykułu Zoli, jak i głośnego obrazu Gance’a, poszerzając wymowę filmu poza ramy wyznaczone tematem głównym, czyli aferą Dreyfusa.

Ostatni kadr z Oficera i szpiega burzy wrażenie szczęśliwego zakończenia, jakim wybrzmiewa scena spotkania obu protagonistów w gabinecie mistrza wojny. Oto oglądamy leżącą na placu złamaną szablę oficerską Dreyfusa i zdarte $\mathrm{z}$ jego ramion epolety, obraz wyjęty z pierwszej sceny filmu i ponownie pokazany na jego zakończenie. Znak pęknięcia, którego nie da się już skleić. Niepokojący symbol końca stulecia. Świat wkracza $\mathrm{w}$ nowe $\mathrm{z}$ tą złamaną szablą niewinnie upokorzonego i prześladowanego żydowskiego oficera. Zaczyna się era kina. Jakże ironicznie i gorzko mogą zabrzmieć umieszczone w tym kontekście (celowo i z pewną premedytacją) słowa Bolesława Matuszewskiego, jednego z operatorów braci Lumiére, i pierwszych teoretyków kina, który w 1898 roku (tym samym, w którym ukazał się list otwarty Oskarżam! Zoli) z pasją i nadzieją pisał w wydanej w Paryżu broszurze Ożywiona fotografia, czym jest, czym być powinna (La Photographie animeé, ce qu' elle est, ce qu'elle doit être) o wynalazku kinematografu jako nowym źródle historii, a wskazując na możliwe tematy filmowe dla przyszłych kronikarzy, z pełnym przekonaniem zachęcał do kręcenia filmów dokumentalnych o armii:

Nowy wynalazek powinien jednak służyć nie tylko Postępowi naukowemu, może i powinien on służyć również Postępowi moralnemu. Jest on - jak to ukażemy niebawem - skromnym wprawdzie, lecz bardzo użytecznym, a zwłaszcza bardzo wiernym sługą Historii. Weźmy najpierw pod uwagę jeden tylko określony aspekt sprawy: historie pułków, które nie bez słuszności uważa się za nader skuteczny sposób rozwijania u żołnierzy przywiązania do jednostki, w której służą, uczucia będącego niezmiernie ważnym czynnikiem umacniania patriotyzmu. Bowiem miłość do sztandaru wojskowego osiąga prosty żołnierz, ucząc się najpierw kochać swój sztandar. (...) Dzięki temu będzie mogła się rozwinąć solidarność między oddziałem obecnym i dawnym, i to ze skutecznością, którą trudno osiągnąć na drodze najbardziej wymownych wypowiedzi ustnych. Uczucia te będą tym intensywniejsze, im bardziej będą mogły wspierać się na emocjonujących wydarzeniach związanych z dziejami wspólnej rodziny wojskowej. Będzie się uważnie patrzeć w twarze, mniej lub więcej wymowne, postaci, które przyczyniły się do chwalebnej legendy, bowiem spełniły swój obowiązek, dając przykład posłuszeństwa i świadomego zapomnienia o sobie samym (Matuszewski 1980, 157, 159)

\section{Bibliografia:}

Arendt Hannah, 1989, Korzenie totalitaryzmu, Grynberg D., Szawiel M. (przeł.), Warszawa.

z grobów podnoszą się niekończące się szeregi poległych żołnierzy, pragnących się dowiedzieć, czy ofiara była potrzebna. Kontrast dla «przebudzonych zmarłych» stanowi defilada zwycięzców wpisana w wydzieloną część kadru. Ten porażający finalny akord filmu przekształca go «we wspaniały hymn na cześć pokoju»" (Kolasińska-Pasterczyk 2009, 723). 
Bieńkowska Ewa, 1999, Spór o dziedzictwo europejskie. Między świętym a świeckim, Warszawa.

Budzanowska Anna, Pietrzykowski Tomasz, 2020, Wokół procesu Dreyfusa. Jednostka. Ideologia. Polityka, Kraków.

Doherty Thomas, From Méliès to Polanski: The Dreyfus Affair of Film (Preview), https://www.cineaste.com/fall2020/melies-polanski-dreyfus-affair-on-film (dostęp: 12.11.2020).

Harris Robert, Oficer i szpieg, 2020, Niewiadomski A. (przeł.), Warszawa.

Horoszewicz Michał, 2017, Sprawa Dreyfusa. Ostrzeżenie sprzed wieku, Warszawa.

Kluba Henryk, 2001, Podstawy inscenizacji, Łódź.

Kolasińska-Pasterczyk Iwona, 2009, Francuska szkoła impresjonistyczna w: Lubelski T., Sowińska I., Syska R. (red.), Historia kina. Kino nieme, Kraków, s. 723.

Lubelski Tadeusz, 2009, Lumière i Méliès: fotograf i iluzjonista inicjuja kinematograf, w: Historia kina. Kino nieme, Lubelski T., Sowińska I., Syska R. (red.), Kraków, s. 127-128.

Matuszewski Bolesław, 1980, Ożywiona fotografia, czym jest, czym być powinna, w: Bolesław Matuszewski i jego pionierska myśl filmowa. Dokumenty i wstępne komentarze, Czeczot-Gawrak Z. (przeł.), Warszawa.

Osterhammel Jürgen, 2013, Historia XIX wieku. Przeobrażanie świata, Drozdowska-Broering I., Kałążny J., Peszke A., Śliwińska K. (przeł.), Poznań.

Plesnar Łukasz A., Syska Rafał, 2011, Kino amerykańskie lat 50: złota dekada, w: Historia kina. Kino klasyczne, Lubelski T., Sowińska I., Syska R. (red.), Kraków, s. 815.

Polański Roman, 1989, Roman, Szymanowscy K. i P. (przeł.), Warszawa.

Poliakov Leon, Historia antysemityzmu, 2008, Rasińska-Bóbr A., Hademann O. (przeł.), Kraków.

\section{O Autorze:}

Mikołaj Jazdon - dr hab., prof. UAM, filmoznawca, pracuje w Instytucie Filmu, Mediów i Sztuk Audiowizualnych Autor książek poświęconych polskiemu filmowi dokumentalnego (Dokumenty Kieślowskiego, Polskie kino niezależne [redaktor tomu] i Kino dokumentalne Kazimierza Karabasza) oraz artykułów publikowanych w kraju i za granicą po angielsku, niemiecku, hiszpańsku, duńsku, czesku, słowacku. Autor wywiadu-rzeki z Krzysztofem Piesiewiczem, Kieślowski. Od Bez końca do końca. Współredaktor Kieślowski Revisited (and Re-watched), numeru monograficznego IMAGES (2018 nr 33). Współautor opracowań do wirtualnego spacerownika tropem miejsc związanych z realizacją Dekalogu Krzysztofa Kieślowskiego (mapadekalogu.pl). Ekspert Polskiego Instytutu Sztuki Filmowej w latach 20142107. Autor opracowań do albumów z filmami DVD z serii Polska Szkoła 
Dokumentu (Krzysztof Kieślowski, Kazimierz Karabasz, Władysław Ślesicki, Czarna seria oraz Gryczełowska, Halladin, Kamieńska). Współautor scenariuszy do 12 odcinków telewizyjnej serii Sztuka dokumentu (2008). W latach 1997-2016 prowadził Klub Krótkiego Kina w poznańskim Centrum Kultury Zamek, czyli cykliczne pokazy i spotkania autorskie. Kurator przeglądów w ramach festiwali Hommage a Kieślowski w Sokołowsku. Dyrektor artystyczny Międzynarodowego Festiwalu Filmowego „Off Cinema” w Poznaniu. 
